\title{
The Laicity of the State in Situation in Cameroon: Between Constant Interferences of Politics and Religious and Doubtful Neutrality of the State
}

\author{
Florent Guy Atangana Mvogo \\ Lecturer in the Faculty of Law and Political Science \\ University of Ngaoundéré, Cameroon \\ Email: atanganamvogoflorentguy [AT] yahoo.fr
}

\begin{abstract}
Cameroon has constitutionally taken the option of secularism. But in everyday life, we see that politics and religion are strongly intertwined through interference, sometimes combination and sometimes pathology. In addition, the supposed neutrality of the state vis-à-vis the religious suggests that some actors in the religious segment are privileged over others.
\end{abstract}

Keywords---- Secularism- Cameroon- Political-Religious Interference- Questionable Neutrality

\section{INTRODUCTION}

The sociological studies of a society reveal a doctrinal controversy that brings out three fundamental paradigms. The first two of these paradigms lead to the individual / society dichotomy, thus referring to methodological individualism on the one hand and to methodological holism on the other. Methodological individualism is in goes in hand with strategic interactionism. It makes a society as an aggregation of individual behaviors. As such, it favors the study of microsociological relations to infer macro-social phenomena. Social actors, individuals or groups, thus become the basic elements of societal dynamics.

On the other hand, methodological holism perceives a society as a separate entity and subject to specific laws. These laws are shaped by a system of determinisms and constraints to which society is summed up. Thus, one insists in the framework of this methodological approach on the social determinisms which govern the agents. The term agent used here refers to the passive or acted individual who suffers the blows and repercussions of social determinisms, as opposed to the actor who is at the heart of methodological individualism and who evokes the individual as active subject in the society.

Between these two paradigms, situated at the antipodes from each other, is found the constant paradigm of the interpenetration of individual and collective behaviors. Refusing the individual / society dichotomy as it opposes the first two approaches, this paradigm cuts the pear in half. To sum up this paradigm, the society refers to a complex configuration of interactions in a socially organized situation.

Much more than any other type of society, the state political society reflects these complex configurations of interactions in a socially organized situation. This is because it is based on the highly complex and global phenomenon of institutionalized political power that regulates both individual and collective enterprises. The developments that follows subscribe to the paradigm of the interpenetration of the individual and the society as a whole. It is therefore important for us to apprehend the constant interactions between the religious and the State in the multi-confessional context in particular of the Cameroonian political society. By religious, we must understand that which relates to religions, insofar as they are a constellation of groups of organized individuals who, through rites and dogmas, claim to establish a bond of belief between the individual and one or supreme supernatural forces called divinity. As for the state, it is perceived as a statepower, i.e. "social subset that feeds a fearful claim to colonize the entire social field" (Lerroux 1989: 123). These clarifications made, it must be noted that the issue of the relationship between the spiritual and the temporal, the religious and the political is present in all political societies and involves cultural relativism. In Cameroon, the principle that structures the interactions between religion and politics is secularism. At the highest level of the hierarchy of state norms, this principle suggests a twofold idea: the neutrality of the State towards religions and the non-interference of religions in the activities of the State and Conversely. The place of enunciation of this principle is in itself, symbolically, an indicator of the importance which is accorded to it, at least from the theoretical point of view. Beyond this theoretical enunciation, one can question the real scope of state secularism in Cameroon. Does the state in Cameroon merely regulate religious activity without any preference for certain categories of religion? Is religion simply a "Sunday dress" that is far from the 
political concerns of the day-to-day life of the rulers? In the end, what is the concrete articulation of the interactions between religion and politics in the particular context of Cameroon which is marked by the multiplicity of religions, beyond legal priorities? These questions are of great importance when we remember that in the past, the world was crossed by humanitarian ideologies such as sustainable human development or good governance that penetrated the Cameroonian political society as a whole. It is part of the current process of globalization, and which in one way or the other coincides with the humanistic project of religions. Given these facts, it cannot be denied that the interpenetration of politics and religion is a constant feature of Cameroonian political life (I), but especially that in the context of the proliferation of religious groups characteristic of Cameroon, State's preference for certain religions without making them state religions. This situation tends towards the zero neutrality of the latter towards religious groups (II).

\section{I- CONSTANT INTERPENETRATION OF RELIGIOUS AND POLITICS IN CAMEROON}

Despite the historicity of the principle of the separation of religion and politics, religion and politics in Cameroon have always been strongly intertwined.

\section{I.1. The historicity of the principle of the separation of religion and politics}

The principle of the separation of religion and politics, which is at the foundation of the secularism of the State, has, on the historical level, a doctrinal anchorage before being translated into practice by certain modern states, considered as pioneers in this regard.

\section{I.1.1. The doctrinal anchorage of the problematic of the separation of politics and religion}

The problematic of the relations between the political and the religious is as old as the men are organized politically and establish a bond of belief with a divinity whatever it is. It has abundantly fed the doctrine with many variances. St Augustine, for example, will speak of the two cities or citizenships: the celestial city and the earthly city. In the perspective of political Augustinism, Boniface III will transform this dualism into dualistic polarity of two swords, temporal and spiritual, by establishing the superiority of the spiritual sword over the temporal sword. Later, Martin Luther will come to reject Augustinian dualism and the theocratical conception of the medieval church (SIEGWAL, 1990). In his doctrine of the two kingdoms, he proceeded to a theological systematization of the relations between Church and State. He grasps the two kingdoms, spiritual and temporal, in the sense of a dialectical polarity, the two poles being both referenced to each other and both, but different from the same God (Luther, 1958). In societies where this relationship has historically been structured, it has generally arisen in terms of spiritual domination over the religious or vice versa, or rather between the two for domination. The problem was who is leading in the name of God, the emperor or the pope? Caesaropapism, or royal theocracy, is one of the most important figures in history that these relationships have touched. Originating from the Roman conception of the imperial power that the emperor would reunite in his person the political destinies of the empire and the religious power, the césaropapisme refers to a system of temporal government that seeks to exercise its power over business religious. It corresponds to Late Antiquity, the Byzantine Empire, and the West to the Ottonian Period.

\subsubsection{Modern consecration of secularism by some pioneer states}

"Give to Caesar what is Caesar's and to God what is God's." This biblical formula seems to sum up the modern creed of the principle of the separation of religion and politics, of the secularity of the state. Historically, this principle has emerged in the relationship between politics and religion in the West according to the circumstances and the socio-political environment specific to each modern state in constitution. In truth, , "the various conceptions of secularism refer to (...) the various experiences of emancipation of the political vis-à-vis the religious that the countries have known, as well as their political culture" (Alcaud et al, 2004 : 189)

It was in the heat of the struggle for independence that the US had to devote the independence of the federal state to religious denominations, as well as freedom of conscience and the absence of any religion established. This act was neither more nor less than a manifestation of the sovereignty of the new independent State. This event, if addressed openly to the church, is also a mark of the break with the prevailing system in formerly colonizing England where the Anglican Church is a state church, headed by the monarch. England for instance, must be remembered, in her enterprise of colonization of the entities that will form the nucleus of the USA has transposed on these territories her conception of the relations between religion and politics. This conception would require the British monarch to be the supreme governor of the Anglican Church. It stems from the historical break in 1584 between Pope Clement VI of the Catholic Church and the King of England Henry VIII, because of the refusal by the pope to cancel the marriage of the latter with Cathérine of Aragon for legitimacy to marry Anne Boyelen. This refusal will lead the King of England to empower the Church of England against the power of Rome, and to claim the title of "Supreme Head of the Church and Clergy of England"

In France, after several centuries of domination of the Catholic Church, secularism has become one of the founding principles of the organization of relations between the state and the major religions (Christianity, Islam, etc.). Originally, she was aggressive, that is to say, denying the religious fact; the socio-political context that emerged explains this refutation 
of the religious fact. With the construction of national unity, it has become a principle of tolerance advocating respect for pluralism of beliefs. After proclaiming that "no one can be worried about his opinions, even religious, provided that their manifestation does not disturb the public order established by the law" (art 10 declaration of the rights of the man and the citizen), France abolish Catholicism as a state religion. The strength of the secular principle in France in the expression of the domination of the church will give rise to an enterprise of secularization in all spheres of human activity: secularization of civil status in 1792, primacy of civil marriage in the penal code of 1810 , abolition of the religious character of cemeteries in 1881, abolition of public prayers at the opening of parliamentary sessions in 1884 etc. The first battleground for secularism in France was school. For a long time dominated by the church, the education system was organized outside any state control until the revolution where this monopoly started, in particular with the decree of 1793 which sustains freedom. With the Ferry Acts of 1881 and 1882, the great principles of secularity and neutrality of education are laid down, the programs set, the teaching staff and primary school pupil laicized, and the religious emblems removed and the moral and civic instruction substituted for instruction moral and religious. The secularization of the public school and the organization of the freedom of education under the control of the State appeared fundamental for the constitution of a nation-state devoid of any reference to the divine order and organized around an egalitarian and universal conception of citizenship. The law of 1905 known as the law of separation of the church and the state dedicates the culmination of the secular conflict, when it lays down the principle of freedom of religion and worship guaranteed by the State, itself autonomous vis-à-vis religions. Secularism is finally constitutionalized in France in 1946 as a system where power belongs to the people, as a united body whose unity is based on the practice of civic virtue, where the differences between individuals are excluded in the name of the ideal national community and reason and, where beliefs are expressed in the private sphere. It is a principle of political organization and social cohesion, a means of uniting differences and creating a community of egalitarian citizens, not dominated by a conception of the world that draws on any religion. It is this conception of the secularism of the state that has been transposed in Cameroon and that the successive constitutions of the country formally declare. This formal enunciation in no way intertwines the character of the two religious and political spheres; it is understood that a situational analysis of the relationship between the state-power and the religious reveals that the waters are not so unraveled as might suggest the constitutional, legal and institutional fascia.

\section{I.2 Religious and politics in Cameroon: two segments of society strongly intertwined}

The constitutive proximity between the sacred and the political, the interaction between religion and politics is a constant feature of human cultures and civilizations. In Cameroon, the interferences between the state-power and the religious goes back to the colonial period, beyond the affinities that politics and religion presented and continue to present in the traditional African political systems (Potholm, 1981) which today they are infra-state. These interferences are similar to interference-combinations, which are added to interference-pathology.

\section{I.2.1 Interference - combination of politics and religion}

By interference-combination, we mean that which results in a synergy of action between the two segments of society in a sense that follows the orientations of the power in place. The interferences-combination between politics and religion in Cameroon are materialized by the latent or manifest multiform support that the religious segment brings to the political segment in its claim to colonize the entire social field. Originally, these interferences are part of a concerted logic of colonial domination of the West on the African continent. This logic is perceptible in the myth of the three explorers' conspiracy in the ship towards Africa, as described by T. ATEBA YENE in his book Mémoire d'un colonisé (Ateba, 1988: 48). There were three in this ship, an administrator, a merchant, and a priest. The priest brought them together and assigned each one a mission. To the administrator, he assigned the mission to frighten people with the rifle, to force them to plant the cocoa and coffee which he arbitrarily set the price, to set a flat rate that all natives must pay annually in the crates of the State, and to compel them to carry in hammocks all the whites and their families moving from one country to another. To the merchant, he entrusted the task of selling his goods to the natives at the highest price, and arranging to buy their cocoa and coffee at the lowest price, even below that fixed by the administration. To himself, he gave himself the mission of serving as an intelligence agent for the administration, and to thwart any desire for rebellion on the part of the natives by brandishing the cross and the rosary and, invoking the Gospel of the mountain where Jesus said: "Happy are the poor because the kingdom of heaven is theirs".

If myths have the shortcoming of having no root in reality because it was a pure constructions of the mind, they have this functional virtue to allow access to the understanding of social reality. The myth of the three explorers in the ship heading for Africa thus provides a key to understanding the close relationship between religion and politics in Cameroon during the colonial period. From this myth, one can understand the open commitment of the churches to the side of the colonial power to fight the Union of the populations of Cameroon (UPC). As the first political party in Cameroon, the UPC was born in April 1948 in the context of the awakening of Cameroonian nationalism. In his political program, he sets himself the ambition of "the big question of the march towards independence" and "the reunification of the two shreds of Cameroon", but his ideological affiliation with the USSR or China, in short with Marxism It is hard to detect (Ngongo, 1982: 204) And yet, it is on the terrain of this ideology that Christian religious forces formulate reservations and condemnations to the UPC (Ngongo, 1982: 207), and synergize with the colonial power to fight this party. This intrusion 
- support of the church in the political sphere in Cameroon of the colonial period materializes variously: confiscation of the cards of the faithful who adhere to the UPC, violent slurs of the party, delivery of the names of the adherents to the party to the civil authorities deprivation of leaders of the party of the sacraments of the church (Mbome, 1979: 170), demonization of the party under the label of atheistic communism condemned by the pope etc.

After independence, the data has not fundamentally changed. The post-independence period reveals a continuity in the connivance between the Christian church and the power of the new independent state. The history of Christian Church-political order relations in Cameroon is littered with open demonstrations of support from it to that one. Thus, in the fight against the rebellion of the UPC, Priest Jean ZOA was offended in October 1960, to condemn it, the proliferation of Marxist publications in Southern Cameroon in these terms "A massive support is orchestrated these days to flood South Cameroon with Marxist publications (...) We say no to the "Sovietization” of Cameroon.(Eyinga, 1978 : 69) On the occasion of the referendum which was to lead to the unification of Cameroon in 1972, it was noted that the National Council of Bishops of Cameroon was determined to mobilize Christians in favor of the political project for the transition from a federal state to a unitary state. The following resolution adopted at the Council meeting of May 17, 1972, as follows:

"The members of the permanent council also know with all other Cameroonians, that Christians are preparing to act Saturday, May 20, a civic act of vital importance for the future of our homeland."

"We express our perfect determination with other fellow Cameroonian brothers and sisters without distinction, to the advent of an effective, just, free and fraternal nation"

"Their willingness to participate actively in the transformation of Cameroon's land will encourage Catholics to fulfill their civic duty by Saturday's vote”. (Eyinga, 1978: 30)

Similarly, during the troubles that punctuated the beginning of the democratic transition in Cameroon in the 1990s, the support of the ruling churches against the centrifugal forces manifested itself under two main facets. The first was for Christian churches to openly condemn the waves of violence that accompanied the protest movement that began in 1990 and to ask the faithful to pray for peace. Admittedly, the ideology of peace and non-violence is not always conservative. It can even be revolutionary as the examples of GHANDI in India and Martin Luther KING in the USA have revealed. But in the context of Cameroon's socio-political crisis against a backdrop of revolutionary violence in the 1990s, this attitude of the Christian churches was a clear contribution to the maintenance of the established order so dear to the ruling order. If not, how to explain that during a march of protest against multipartism organized by the departmental section of Mfoundi of the ruling party, the Cameroon Peolple's Democratic Movement (CPDM) in Yaounde on March 30 , 1990, the archbishop from Yaoundé, his Lordship Jean ZOA, joined the demonstrators in celebrating, to round up the march, a "propitiatory mass by which the party prolonged its reflection", to use the words of the officiant.

The second facet will consist of contradictions within churches such as that between his Lordship Christian TOUMI, Archbishop of Douala whose positions are favorable to the movement for the defense of liberties and democracy in general, and his counterpart Jean ZOA of Yaoundé who inscribed against this movement; or rather the one that emerged in the Federation of Protestant Churches (FEMEC) about a draft letter to the President of the Republic that was to echo the sufferings and aspirations of the people and propose remedies, but which $\mathrm{n}$ will not result from a dissension within the federation (Eboussi, 1987: 389-390), on this subject. These divisions show that a good cohort of churches were behind the ruling order, either by remaining silent as was the case with the Adventist Church, or by openly expressing affinities with power. In addition, these divisions may seem rewarding for power, in that, from the sociological point of view, contradictions contribute to stabilizing power, so much so that, as Mr. EDELMAN points out, "that divisions and dissensions lessen social conflicts and provide a sort of social glue that prevents the explosions, sometimes born of these antagonisms, from turning into revolution (Edelman, 1991: 167)"

Alongside these two facets, we can note with F. EBOUSSI BOULAGA an acculturation of Christian churches to the hegemonic project of the new independent state, with which they comprise despite tensions and crises, with which they often have the same aims and a relationship of connivance in their common claim of universality (Eboussi, 1988: 335). This acculturation justifies the attitude of silence - support of the Christian church in power, faced with an avalanche of highly repressive measures taken by the latter in the 1960s, including the excessive restriction of individual and collective freedoms, the transfer of powers to a military jurisdiction. Regarding the 1962 Ordinance on the repression of subversion F-X MBOME wrote : "Never during the implementation of this famous ordinance will any minister of religion raise (...) any substantive protest concerning his repressive character. This silence of the churches can be interpreted as approving, and hence as a form of strengthening of power" (Mbome, 1979: 117)). This was a latent or implicit support for power, a true unspoken Gospel of Jesus Christ on the Mountain is also evoked in the myth of the three Western missionary settlers on the boat to Africa.

The religious ideologies of peace and justice in the hereafter based on the gospel of the mountain and permanently mobilized by the Christian churches in Cameroon, have always worked for the benefit of power in the sense of the established political order. Indeed, religious belief in a world where present inequalities would be abolished participates in 
technologies of building attitudes of resignation and obedience to the established political order. This political function of conservation and, therefore, support of the religious is emphasized by Napoleon I in these terms "How to have order in a state without religion? When a man dies of starvation beside another who is full, it is difficult for him to reach this difference if there is not an authority which says to him: God wants it so, there must be rich and poor in the world; but then and for eternity, sharing will be done differently" (Duverger, 1966: 24)

\section{I.2.2 Interference - pathology between religion and politics}

These interferences translate sometimes in the form of criticisms of the options of power, sometimes in the form of perceptible tensions between the two segments of the Cameroonian political system. In any case, they reveal the pathological aspect of the relationship between the religious segment and the political segment in their articulation within the political system. Indeed, it has often happened that the actors of the religious segment, individuals or groups, question certain political options of the Government and / or call it to correct social injustices. It is in this logic that the religious segment appeared in many ways as a functional substitute for the opposition during the one-party period. In an article entitled "The Political Function of Churches in Cameroon” published in 1973 in the French Journal of Political Science, Jean-François Bayart highlights this political dimension of religion. In fact, President Ahmadou Ahidjo, in ending the multiparty system in 1966, had deprived the population of instances of expression and demands. The Church and more particularly the Catholic Church, will become the "place of expression of various category interests" (Bayart,1973:514536), thus assuming the function of articulation and expression of interests classically devolved to the parties policies in democracies. In doing so she assumed a tribune function. Jean-François Bayart places the Church in the heart of the arcane political power. For she will become the spokesperson for the oppressed. In the context of prevailing monopartism, it will almost play the role of opposition party. Thus, Jean-François Bayart rightly asserts that "religious leaders make personal interventions to protect people from arbitrary measures" (Bayart, 1973: 514-536). Thus, Bishop NDOGMO intervened and often succeeded to annul extrajudicial decisions. In the same way, Mgr. Jean ZOA intervened in the Train Business in 1962 revealed in "The secret Carnets of decolonization". If we stick to these examples, we can say that the religious segment has in many ways emerged as a counter-power in the absence of political parties of the opposition or rather face their extreme weakness. We are faced here with what Robert King MERTON called functional equivalent or functional substitute. This formula refers to the situation in which, in a political system, a single element may have several functions, just as a single function may be filled by interchangeable elements, such that an element serves as a substitute or functional equivalent to a single element and on the other hand to carry out the same activity alongside or in its place (Merton, 1965: 118). This posture of the religious segment as a functional substitute for the elements to be used as counter-power in the Cameroonian political system of the single party is present in the doctrine and the social philosophy of the Catholic Church at the highest level, with regard to the dictatorial governments of Africa. It can easily be detected in this speech by Pope John Paul II in Ecclesia in Africa:

"The foundations of good government must be built on the sound foundation of laws that protect rights and define the duties of citizens. It must be well-known with great sadness that many African nations are struggling under authoritarian and oppressive regimes that deny their members personal freedom and fundamental human rights, especially freedom of association and political expression as well as the right to choose their rulers by means of free and impartial elections [...] This is why the Synod has rightly considered that authentic democracy, with respect for pluralism, is "one of the main roads on which the Church walks with the people. [...] The Christian layman engaged in democratic struggles according to the spirit of the Gospel is the sign of a Church that wants to be present in the construction of a state of law everywhere in Africa" (John Paul II , 1985)

Moreover, the interference-pathology between the political segment and the religious segment is not always limited to criticisms and / or questions of the religious segment to the address of the policy for more social justice and respect for human dignity. From time to time they encounter perceptible tensions or crises. With regard to the Catholic Church, these crises and open tensions have often been based on suspicions that one can weigh on the other or vice versa. This is so with the plot of the Holy Cross in August 1971 when Bishop NDOGMO Albert, Bishop of Nkongsamba was arrested and tried with 76 other people, suspected of having:

- "organized and commanded an armed band with the intention of attempting by violence, either to modify the constitutional laws or to overthrow the political authorities ..."

- "Attempted to murder the President of the Federal Republic of Cameroon and his close collaborators ..." (journal l'unité, août1970)

At the end of this trial, Bishop NDOGMO was sentenced to death, then his death sentence will be commuted by the President of the Federal Republic of Cameroon in detention for life. This is also the case with the suspicious death of Bishop Jean-Marie Benoît BALLA, Bishop of Bafia. Indeed, on May 31, 2017, Cameroon recorded the "suspicious" death of Bishop Jean-Marie Benoit Balla, Bishop of Bafia. His car was found parked on the Sanaga River bridge in Ebebda. A terse phrase was written on a white paper with an "Archdiocese of Bafia" heading and bearing the handwritten words "I 
am in the water". After a search of more than 48 hours, his body was found on June 2, $20177 \mathrm{~km}$ from the bridge by fishermen. The official thesis of drowning suicide put forward by the Attorney General of the central region to which the investigation had been entrusted was openly questioned by the dignitaries of the Catholic Church including the President of the Episcopal Conference of Cameroon, Joseph KLEDA, Archbishop of Douala. They thought it was an assassination. This contradiction between the official version of suicide and the position of the dignitaries of the Catholic Church reflected a perceptible tension between the Catholic Church and the government. It was based on suspicions that the collective imagination of the Catholic community weighed on the power over this death; especially since many other cases of "suspicious" death of religious had preceded that of the bishop of Bafia, under conditions that have never been elucidated despite investigations ordered by the authorities.

In the early 1990s, a crisis pitted power against the Muslim community of Yaoundé, with a risk of conflagration in other parts of the national territory where the Muslim religion was well established, and even the deterioration of diplomatic relations between the country. Cameroon and the Islamic world. This crisis was made against a backdrop of land dispute. Indeed, wanting to materialize the construction project of the Islamic complex of the Servant-of-the-TwoSaints-Mosques (commonly called big mosque) of Tsinga district and financed by partners of the Islamic world, the Islamic religious leaders of Yaoundé received an end of not to receive by public powers on the grounds that the land covered by this project was not the property of the Islamic community. In the context of a socio-political crisis in the midst of the withdrawal of identity that marked the early 1990s in Cameroon, this crisis was, with the help of the so-called opposition private press, rapidly transposed into the political arena, culminating in a physical confrontation between law enforcement and Muslim faithful. Muslim opinion leaders and the so-called opposition private press managed to crystallize in the imagination of followers of the Islamic religion that it was an identity-based conflict, which made this open conflict strong ideological, and therefore emotional charge.

The foregoing analysis show that religion and politics in Cameroon, if strongly interwoven, do not merge. There is therefore between these two segments of the political system a separation that deserves to be put into perspective to the point where the political segment, without making state religions gives preference to certain religions.

\section{II- THE MARKETED PROPENSITY OF THE STATE-POWER IN CAMEROON TO PRIVILEGE CERTAIN ACTORS OF THE RELIGIOUS SEGMENT: TOWARDS ZERO NEUTRALITY?}

The concept of state secularism implies that, beyond the separation of religion and politics, the neutrality of politics vis-à-vis the different religious groups that unfold on the national territory. In Cameroon, this neutrality is more clamorous than practiced. There is indeed a propensity of the state-power to reserve a privilege treatment to certain segments of the religious compared to others. These privileges take the path of the diplomatic recognition of certain actors of the religious segment, but also of their strategic protection and their representation in certain institutional organizations of the State. This posture of the state-power tends toward zero neutrality and, consequently, leads to questioning or at least to relativize strongly the neutrality of the State vis-à-vis religions in Cameroon.

\section{II.1 The diplomatic status of certain actors in the religious segment as a discriminating factor}

Islam and the Roman Catholic Church are considered privileged actors in Cameroon in view of their place in the country's diplomatic spectrum, compared to other actors in the religious segment (animism, Adventist Church, Protestantism, Pentecostalism, so-called revival churches, etc.)

\section{II.1.1 The Roman Catholic Church in the Diplomatic Chessboard of Cameroon}

Diplomatic relations, in the practice of the modern international community, are in the exclusive domain of States (in the sense of constitutional law and public international law) and international governmental organizations. The Catholic Church, which leans on a sui generis State, namely the Vatican State, enjoys a special status which justifies the preferential treatment it enjoys in Cameroon in relation to other religious obedience that are entitled to it. This State, of a living symbol of the Catholic Church, is diplomatically represented in Cameroon by the Apostolic Nuncio.

To better understand the privileged status enjoyed by the Catholic Church in Cameroon, we must go back to the Lateran agreements that recognize Italy's recognition of the Vatican State. The latter are a set of three diplomatic texts, the best known of which is the treaty between the Holy See and Italy. They are signed at the Lateran Palace on February 11, 1929 between the Kingdom of Italy, represented by the President of the Council of Ministers Benito Mussolini, and the Holy Seat, represented by Cardinal Pietro Gasparri, Secretary of State of Pope Pius XI. They intervene in the framework of the appeasement of the conflict which opposed the kingdom of Italy to the Catholic Church. Indeed, in 1870, General Cadorna invaded the Papal States and Rome became the presumptive capital of the Kingdom of Italy. Pope Pius IX was forced to flee to the Vatican and considered himself a prisoner. In 1871, the Italian Parliament voted a "law of guarantees" to guarantee the prerogatives of the pope that it refused. This refusal of the pope provoked a disagreement between the kingdom of Italy and the Roman Catholic Church which will last 60 years. Only after the First World War did the Church, the Italian government and the moderate liberals get closer and the Catholics reinstated political life. With the advent of 
fascism, the church bet on the least hostile components of fascism; this resulted in the reform of the ecclesiastical laws of 1923-1925, favorable to the Church.

It was Mussolini's speech on January 3, 1925, which marked the restoration of good relations between the Holy See and the Italian Government. It is in this context that the Lateran agreements come into play. Ratified on June 7, 1929, these put an end to the "Roman question", which occurred in 1870 after the capture of Rome and its annexation by the Italian monarchy. They reduce the temporal sovereignty of the pope to the only state of the Vatican City and confirm that the Catholic, Apostolic and Roman religion remains the only religion of the Italian state, in accordance with the status of the kingdom of 1848. By these agreements, the Pope agrees to no longer be temporal ruler except in the Vatican City, whose full ownership and sovereign authority to the Holy See is recognized by the Italian State. Any form of Italian interference is abandoned. In compensation, the Holy See renounces all claims on the former Papal States. He recognizes the kingdom of Italy under the house of Savoy, and Rome as capital of the kingdom of Italy. Italy, for its part, recognizes in Rome a "città sacra"; which concretely means that Italy takes the Vatican under its protection. Thus, in the event of an incident on St. Peter's Square, the Italian police must intervene. The new state of public services is recognized as a currency (the Vatican lira), a press organ, a radio and a television with the right to emit, etc. The Vatican State, the last remaining remnant of the Papal States, becomes the instrument of the Holy See, a person of international law, defined as the set of superior Catholic institutions. The preamble of the pact provides: "Since, in order to assure the Holy See of absolute and visible independence, it must be guaranteed indisputable sovereignty, even in the international sphere". It was realized that it was necessary to set up, with particular modalities, the Vatican City, recognizing to the Holy See, on this very City, full ownership, exclusive and absolute power, and sovereign jurisdiction. This will mean that the pope will be recognized as the Vatican's temporal head of state, with all the legislative, executive and judicial powers. The new pontifical territory is made up of 44 hectares, making the Vatican the smallest state in the world. Despite its small size, the Vatican State has a dense diplomatic network deployed through 179 states including Cameroon, and is present at the UN as an observer and member of many UN organizations or agencies.

The Catholic Church is certainly not the only church in Cameroon. Still, the diplomatic relations between Cameroon and the Vatican State give it a stature of privilege. These relations date back to 1966, following the official visit to the Vatican by President Ahmadou Ahidjo. The Holy See had immediately opened an apostolic nunciature in Yaounde and Cameroon, a Chancery in Rome. In order to consolidate the relationship, President Paul Biya will appoint a resident ambassador to the Holy See in 2002, ending a tradition that the Vatican should be covered by the head of Cameroon's diplomatic mission in Italy. Diplomatic actions reinforce the position of the Catholic Church in Cameroon and cause the problems of the latter to be settled at the summit through diplomatic channels through, for example, the signing of bilateral treaties. Thus, on July 5, 1985, Cameroon and the Holy See signed an agreement on the headquarters of the Catholic University of Central Africa of Yaounde. Another more global and immediately applicable agreement will be concluded between the two institutions on January 13, 2014 relating to the status of the Catholic Church in Cameroon. The latter sets the rules governing relations between the Catholic Church and the State of Cameroon. The privileged position of the Catholic Church in Cameroon can be explained, beyond the moral authority of this one because of what it works in the field of the faith, by its important implantation in the sensitive education field, health and social affairs. Indeed, the action of this church in these three areas is perceptible by the creation until 2014 of 350 nursery schools, 1005 primary schools, 139 secondary schools, seven universities (including the Catholic University of Central Africa), 23 hospitals (including the Shisong Reference Hospital in the North West Region, home of the only cardiology center in West and Central Africa where open heart surgery is performed), 228 clinics, 10 leprosaria, 11 nursing homes home, 12 orphanages (Cameroon Tribune of April 29, 2014)

\section{II.1.2 Islam and Cameroonian diplomacy}

In 1972, the Organization of the Islamic Conference (OIC) was created, a transcontinental international governmental organization grouping the Islamic States whose aims are among others:

- Consolidate Islamic solidarity among members;

- Coordinate action for the safeguarding of holy places, support the struggle of the Palestinian people and help them recover their rights and liberate their territories;

- Consolidate the struggle of all Muslim peoples to safeguard their dignity, independence and national rights.

The Cameroon adheres to the umbrella organization of states that have a connection more or less told to Islam in 1975. By this diplomatic act, Cameroon scored his attachment to this religion not as a state religion, but religion weighs on the national political scene; especially since he was headed by a Muslim head of state. This privileged place given to Islam in the political and diplomatic arena was to be confirmed 22 years later by the creation, December 7, 1997, in favor of a cabinet reshuffle, a deputy minister position to the Minister external relations responsible for relations with the Islamic world. This post will be entrusted to a Muslim native of the Far North which is among the highly Islamized regions of Cameroon. Through this position, special attention is given to Islam through strong concept meaning of "Islamic world" 
which, obviously, means countries which apply or whose political systems are strongly influenced by Islamic laws as Saudi Arabia. Unlike the Catholic Church, which rests on a State (Holy See), Islam, for its mark strongly the political process in Cameroon, draws its strength from the solidarity of the Islamic world throughout the United Islamic, the OIC and its instruments as the Islamic Development Bank (IDB). The latter is present in Cameroon through an active portfolio in terms of investment which amounted in 2017 to 500 billion CFA francs (see Cameroon forum of 27 September 2017), which is managed by a local representative of this institution. In 2009, Saudi Arabia, through the Saudi Development Fund, participated in development projects in Cameroon up to 23.90 billion CFA francs. The Fund has had to finance many development projects such as the Foumban-Magbe road, the bridge over the Mape, the Ayos-Bonis road, hydroelectric dam Song-Loulou, the railway Eséka- malume, the extension of the University of Ngaoundere, the Tsinga Islamic complex in Yaoundé (Ngiamba, 2009: htt // www / newspaper du Cameroun of 02-07-2009), etc. It can be seen, as in the case of the Catholic Church, that the solicitude of the Islamic religion can partly be explained by a game of interest, states having no friends but only interests to defend.

\section{II.2 The strategic protection and representation of certain religious segments in state institutional bodies}

There are two other indicators of discrimination in the Cameroonian political system between religious segments. The first lies in the fact that under President Ahidjo, the ruling order had a propensity to protect or subtly promote Islam in some parts of Cameroon. The second is that in the ideological movement of good governance, and therefore the need for participatory management, the actors of certain segments of the religious are represented in institutional bodies of the State to the exclusion of others yet are also part of the religious landscape of Cameroon.

\section{II.2.1 Propensity to strategically protect and subtly promote Islam in North Cameroon under the AHIDJO regime}

Numerous studies done on North Cameroon show that during the reign of Ahmadou AHIDJO, the state favored Islam and Muslims. In this part of the territory during this period, Mr. AHIDJO's "resolutely Islamic politics" (Bayart, 1985), led to spreading the image of the North as a homogeneous society under the command of Muslims and the religious domination of Islam. . It was about strategically protecting Islam and promoting it subtly. The strategic protection of Islam was against the expansion of Christianity. For the hebrew ethnic hebrew bearers of Islam, to which belonged President AHIDJO, this religion was the only one on which political authority could be based. For eminently political reasons related to the fact that the Christian church, especially Catholic, possessed the ideological and organizational potential to reunite the Kirdi groups and create a collective identity that could effectively oppose the Islamo-congregated hegemony, the authorities undertook to curb the political commitment of Christian churches. Two mechanisms allowed the company to block Christianity for the benefit of Islam, with the blessing of the administrative authorities. The first was to prevent the establishment of Christian churches by obstructing the process of acquisition of land by them. Thus, in 1960, Kaélé's chief designated a site for the construction of the Catholic mission. The Divional Officer faced this situation discreetly instructed the service of the domains not to carry out the demarcation, thus preventing the establishment of the land title for the benefit of the Catholic mission. Two similar cases were experienced in Guisiga country. In Moutourwa, the construction of a Catholic chapel was delayed for more than 10 years. The second will have been to intimidate the Kirdi people to prevent their conversion to Christianity, with the understanding that Christianity represented a latent political danger for the hegemonic Muslim regional bloc.

The promotion of Islam for its part went through a kind of "state patronage" (Childer, 1991) that allowed nonMuslims who had Islam to benefit from favors and benefits from the state. The strategy was to appoint to the posts of the territorial administration (governor, Senior Divisional Officers, Divisional Officers) in the North of the country of the Fulbe citizens carrying the values of Islam. These constituted a clientele among the leaders of the non-Islamized populations, and through this clientele, pressure was put on the populations in favor of their conversion to Islam. "Senior Divisional Officers, Divisional Officers had (...) a lot of political resources at their disposal" (Burnham, 1991: pp73-102) in this perspective. Ousmane MEY, "the irremovable governor" (Bayart, 1985: 10) of the North "had an almost mono-ethnic policy in favor of the citizens of the category fulanis" (Burnham, 1991: pp73-102) in the recruitments of the Senior Divisional Officers and Divisional Officers. They made it their duty to work in an unofficial way (because of the constitutional option for the Laïc State) in favor of the conversion of populations to Islam. Thus in the Kaele region of Far-North Cameroon, the number of Islamized chiefs increased from $7 \%$ in 1960 to $36 \%$ in 1972, to a peak of 56\% in 1982. Similarly, after the conversion of their leaders, 570 people burned Islam in the village of Midjivin, 168 in Boboyo and small Muslim communities were created in some Kirdi villages such as Djoma, Piwa, Gaban, Moumour and Moutourwa (Childer, 1991)

Beyond "state patronage" and various pressures on non-Muslim populations in favor of their Islamization, the process of Islamization from above in North Cameroon will also borrow the domain of public symbols: Islamic names given to new neighborhoods in cities, ban on marketing pork and alcohol in local markets, etc. Even today, some public structures bear the marks of this Islamization to the forceps. In the city of Ngaoundere for example, the urban community of Ngaoundéré has created an entertainment structure called «Bois de mardock » which includes a restaurant where the consumption of pork and alcohol is prohibited. Likewise, in the Ngaoundéré University campus, spaces created by the Islamist staff of the University for prayer at hours of prayer, under the watch eye of the university authorities, and in 
defiance of the principle of secularism of the 'State. The concept of flexibility, called administrative tolerance, plays a major role here and endangers the constitutional principle of secularism of the state. The same is true of the mosques built along the roads of the city whose activity, Friday afternoons at prayer time, considerably disturbs the circulation, and therefore the public order, because of the faithful who invade the roadway with their mats under the silent complicity of the administrative police authorities of the city.

\section{II.2.2 The representation of the actors of certain religious segments in the institutional bodies of the State through nominations}

Cameroon is firmly in the global ideological movement of good governance. The establishment of a national governance program in August 1998, the execution of which was conditional on the achievement of the completion point for HIPC (Highly Indebted Poor Country) resources, is an indicator of this accession. In the context of liberal democracy, governance refers to interactions between the state, the body politic and society, and therefore also to the system of lobbying and coalitions of public and private actors. Good governance aims to make public action more effective, close to the public good and the general interest. Thus its mechanisms lead to the establishment, within the State, of a certain number of inclusive institutions which guarantee a participative management of the public sphere likely to render public action effective and legitimate. Beyond the considerations related to the good appropriation or not of the founding tools of good governance by Cameroon, it must be recognized that in the framework of democratic governance, the country has a certain number of institutions that associate the civil society of which segments of the religious belong. Thus, the law that creates the National Commission of Human Rights (CNDHL) provides that it is composed among others representatives of religious denominations appointed by presidential decree. In his current composition we find as representative of the religious confessions Monsignor MONGO BEHON Sébastien, Catholic bishop and Secretary General of the Episcopal Conference of Cameroon, Reverend NGETE Philipe of the Evangelical Church of Cameroon and President of the new Synodal Region Center and South, and ABBO Mohamadou Imam representing the Islamic confession. In many cases, the text creating the public institution does not make any obligation to appoint representatives of religious denominations, but the power is made to appoint dignitaries of certain religious denominations. Thus at the National Council of Communication, Mgr. Joseph BEFE ATEBA (Catholic bishop of Kribi) was appointed president; At Electoral Council of Elections Cameroon (ELECAM), Monsignor Dieudonné WATIO (bishop of Bafoussam) and Ahmadou GOUROUDJA (imam in a mosque in Ngaoundéré and university teacher who died shortly after his appointment) were appointed members; at the National Commission against Corruption (CONAC), Rev. Dieudonné MASSI GAMS (Protestant) was appointed president; at the National Commission for Bilingualism and Multiculturalism, the abbot Jean Marie BODO (Catholic priest) was appointed member. In the light of the preceding examples, it is tempting to conclude that only certain religious denominations, in particular the Catholic Church, the Protestant Church and Islam, benefit from the solicitude of the power in terms of appointment in the public authorities that favor the management participatory in the governance system set up in Cameroon. There is therefore a whole section of the religious segment that is excluded from this process (Adventist church, Pentecostal churches, so-called revival churches, animists)

\section{CONCLUSION}

If the secularity of the state is translated by two options that structure the relations between religion and politics (the noninterference of politics in religious affairs and vice versa, and the neutrality of politics vis-à-vis religions). It should be noted that Cameroon, which forms a formal part of the secular option, seems to be deviating from this trajectory. Indeed, the history of Cameroon is rich in situations of political and religious interference that sometimes translate the connivance between the two, sometimes the conflict. The non-interference of the religious in the political and the political in the religious does not stand the test of the facts. Similarly, the more or less pronounced propensity of the state in Cameroon to favor certain segments of the religious relative to others, identifiable through a number of indicators, leads us to question the true scope of neutrality of the State vis-à-vis the religious segments in Cameroon. One is tempted to wonder whether this double situation does not make the proclaimed secularism of the state in Cameroon a myth?

\section{BIBLIOGRAPHIC INDICATIONS}

$>$ Alcaud D. (2004), Dictionnaire de sciences politiques et sociales ; Sirey, , (sous la direction de ...) .

$>$ Ateba Yene T. (1988), Mémoire d'un colonisé ; l'Harmattan

$>$ Balandier G. (1967), Anthropologie politique ; Paris, PUF

$>$ Bayart J-F. (1973) ; «La Fonction politique des églises au Cameroun, Revue française de science politique, 23(3), pp514-536

$>$ Bayart J-F (1985) ; L'Etat au Cameroun ; Paris, Presse de la Fondation des sciences politiques, 2è éd.

$>$ Burhnam P. (1991), L'ethnie, la religion et l'Etat : le rôle des peuls dans la vie politique et sociale du NordCameroun », Journal des africanistes, 
$>$ Childer K. (1991), « l'Etat et l'islamisation du Cameroun (1960-1982)», Politique africaine n41, mars

$>$ Duverger M. (1966), Sociologie politique ; Paris, PUF, Coll. Thémis,

Eyinga A. (1978), Introduction à la politique camerounaise ; Paris, Anthropos,

Eboussi Boulaga F (1997), La démocratie de transit au Cameroun, Paris, L'Harmattan

$>$ Edelman M.( 1991), Pièces et règles du jeu politique, Paris, édition Seuil,

L Lewellen T. (1983), Political Anthropology: An introduction; 2nd edition, South Hadley, Mass Bergin \& Garvey,

$>$ Lerroux A (1989); La France des quatre pouvoirs. Essai pour une politique humaniste ; Paris, PUF

$>$ Luther M. (1958) De l'autorité temporelle et des limites à l'obéissance qu'on lui doit ; œuvre IV, Labor et Fides ; Genève

$>$ Mbome F-X (1979), L'église et l'Etat au Cameroun ; thèse de doctorat d'état, en science politique, Paris II, Panthéon Sorbone,

$>$ Merton R..K (1965), Eléments de théorie et de méthode sociologique ; trad, 2éd

$>$ Siegwalt $(\mathrm{G})$; «Les deux règnes »; Revue d'histoire et de philosophie religieuses ; vo70, 1990/2, p165 à172.

$>\quad$ Ngongo (LP) ; Histoire des forces religieuses au Cameroun ; paris, Karthala, 1982

$>$ Potholm (C P); La politique africaine : théorie et pratique ; Paris, 2è éd. ; économica, 1981. 